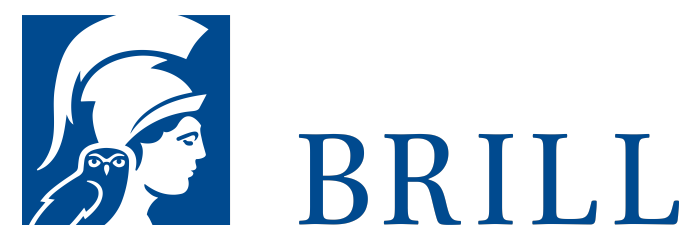

\title{
Wehrmacht und Besatzungsherrschaft im Russischen Nordwesten 1941 - 1944
}

Praxis und Alltag im Militärverwaltungsgebiet der

Heeresgruppe Nord

Author: Jürgen Kilian

Die 9ootägige Belagerung Leningrads stellt eines der großen Verbrechen des Ostkrieges dar. Das Schicksal der Zivilbevölkerung, die im Umland der Metropole an der Neva unter die Herrschaft der Wehrmacht geriet, ist jedoch bis jetzt in der Forschung vernachlässigt worden.

Die vorliegende Studie zeigt hier ausführlich die vielfältigen Motive und Handlungsoptionen eines militärisch dominierten Besatzungsapparates. Denn auch im russischen Nordwesten kam es zu eklatanten Verstößen gegen Völkerrecht und Humanität (Ermordung von Juden, Roma und Geisteskranken, rücksichtslose Partisanenbekämpfung).

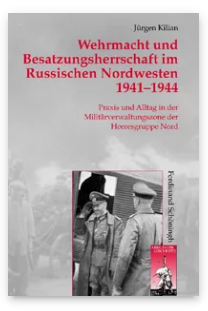

Pages: 656

Seiten, $6 \mathrm{~s} / \mathrm{w}$

Abb.

Language:

German

Subjects:

Modern History, History

Publisher: Brill | Schöningh

Series:

Krieg in der

Geschichte,

Volume: 75

E-Book (PDF)

Released online:

$26 \mathrm{Jul} 2013$

ISBN: 978-3-

657-77613-9

List price

USD $\$ 131.00$

Hardback

Publication date: 28 Sep 2012

ISBN: 978-3506-77613-6

List price

USD \$131.00 
Jürgen Kilian, Dr. phil., geb. 1973, Studium der Geschichte in Freiburg i. Br.; seit 2011 wiss. Mitarbeiter an der Universität zu Köln, Historisches Institut, Lehrstuhl für Neuere Geschichte. Er wurde für diese Arbeit mit dem Werner-Hahlweg-Preis für Militärgeschichte ausgezeichnet.

For more information see brill.com

Order information: Order online at brill.com +44330 333 o049 | customerservices@brill.com Submission information: brill.com/authors

Titles published by Brill | Fink, Brill | mentis or Brill | Schöningh: +49(o)71 5413279216 | brill@brocom.de 